\title{
VARIABILITY IN BIOCHEMICAL COMPOSITION AND CELL WALL CONSTITUENTS AMONG SEVEN VARIETIES IN GHANAIAN YAM (DIOSCOREA SP.) GERMPLASM
}

\section{Afoakwa EO ${ }^{1 *}$, Polycarp $\mathrm{D}^{1}$, Budu $\mathrm{AS}^{1}$, Mensah-Brown $\mathrm{H}^{2}$ and $\mathrm{E} \mathrm{Otoo}^{3}$}

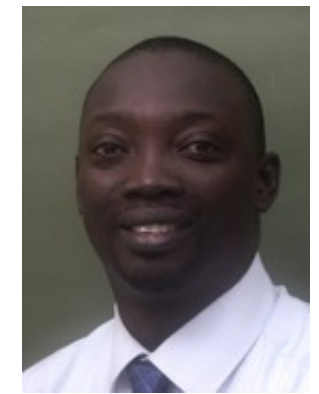

\section{Emmanuel Afoakwa}

*Corresponding Author: eoafoakwa@gmail.com / eafoakwa@ug.edu.gh

${ }^{1}$ Department of Nutrition \& Food Science, University of Ghana. P. O. Box LG 134, Legon-Accra, Ghana

${ }^{2}$ Department of Food Process Engineering, University of Ghana. Legon - Accra, Ghana

${ }^{3}$ Crops Research Institute of Ghana, Fumesua-Kumasi, Ashanti Region, Ghana 


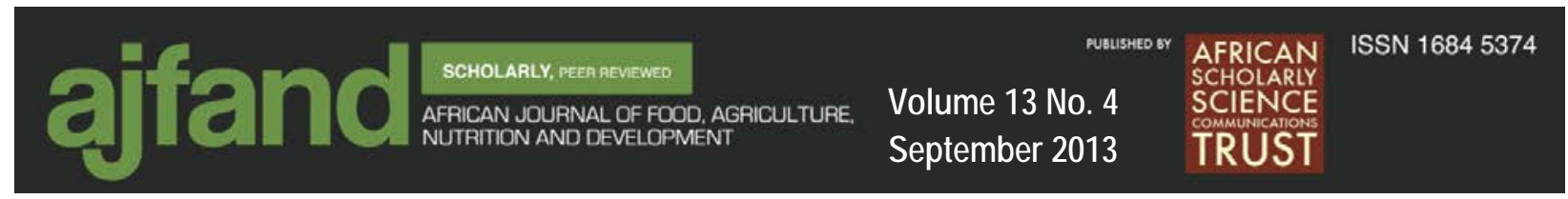

\section{ABSTRACT}

This work characterized the most cultivated and consumed yam (Dioscorea) cultivars within the Ghanaian yam germplasm based on their biochemical and cell wall constituents to assess their potential alternative food and industrial processing applications. Samples were analyzed for their biochemical composition - starch, amylose, amylopectin, total sugars, reducing sugars and non-reducing sugars along the head, middle and tail regions of each tuber using standard analytical methods. Cell wall constituents - acid detergent fibre, neutral detergent fibre, acid detergent lignin, cellulose and hemicellulose of each tuber were also determined using standard analytical methods. The results showed no significant differences at $\mathrm{p}<0.05$ in biochemical compositions along the length of the studied cultivars. D. cayenensis (Pure-yellow), D. rotundata (Pona) and D. alata (Matches) were found to have high starch contents (63.16-65.69\%, 63.54-65.30\% and 63.24-65.17\% respectively). Amylose content was observed to vary along the length of the tubers for the varieties studied. D. alata (Matches) was observed to contain the highest amylose content of 19.66-20.64\%. No identifiable trend was however, observed for the amylopectin content along the length between the varieties investigated. $D$. bulbifera recorded the lowest amylopectin content of $41.29 \%, 43.59 \%$ and $44.63 \%$ while D. esculenta had the highest with $49.84 \%, 50.24 \%$ and $50.13 \%$ along the tail, middle and head sections respectively. Total sugar content varied significantly $(\mathrm{p}<0.05)$ along the lengths of all the varieties investigated. It was higher at the tail portions for all the varieties studied than the head regions; the middle portions recorded the least. D. bulbifera recorded highest total sugar contents (4.74-4.84\%) and total sucrose (3.58-3.64\%). There were significant differences $(\mathrm{p}<0.05)$ in the cell wall constituents of the yam varieties. Cellulose was found to be the most common cell wall component with $D$. rotundata having the highest level of $3.36 \%$ whilst $D$. dumetorum had the least $(1.56 \%)$. Hemicellulose content ranged between $0.42 \mathrm{~g} / 100 \mathrm{~g}$ in D. alata to $4.58 \mathrm{~g} / 100 \mathrm{~g}$ in $D$. esculenta whiles lignin content ranged from $1.56 \mathrm{~g} / 100 \mathrm{~g}$ in $D$. dumetorum to 2.87 $\mathrm{g} / 100 \mathrm{~g}$ for $D$. praehensalis. There were significant differences $(\mathrm{p}<0.05)$ in the neutral detergent fibre found in Dioscorea esculenta and the other yam species. It ranged from $1.18 \mathrm{~g} / 100 \mathrm{~g}$ in D. alata to $5.46 \mathrm{~g} / 100 \mathrm{~g}$ in D. esculenta. Less than $1 \%$ of acid detergent fibre was identified in the yam varieties, suggesting varied levels of biochemical composition and cell wall constituents in the different yam varieties.

Key words: Biochemical quality, cell wall composition, yams

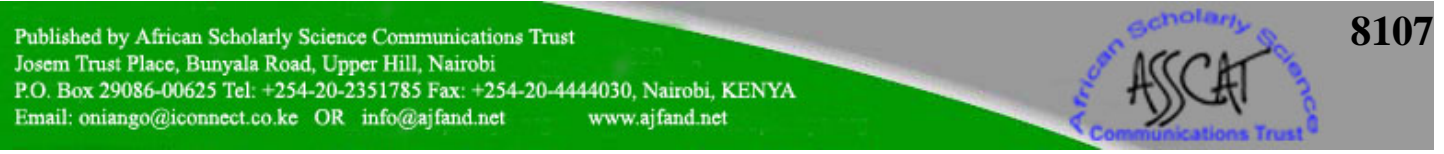




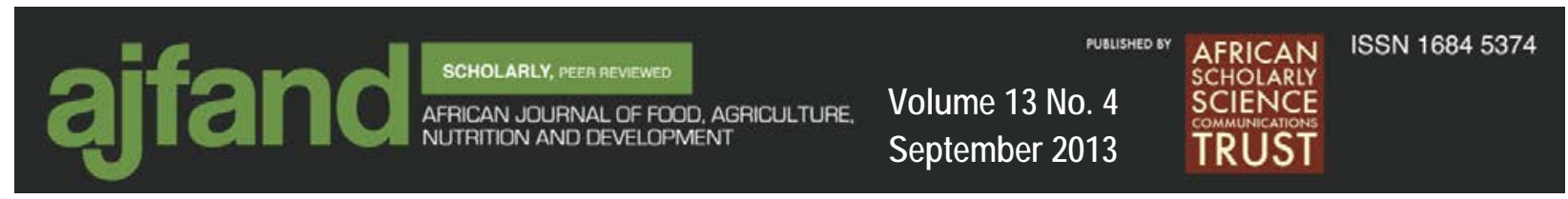

\section{INTRODUCTION}

Yams are tropical-vine tuber crops of the genus Dioscorea which are popular in Africa, the West Indies, and parts of Asia, South and Central America [1]. They are high value crops, cultivated by virtue of their excellent palatability. Yams are produced on 5 million hectares in about 47 countries in tropical and subtropical regions of the world where they are reported to yield about $11 \mathrm{t} / \mathrm{ha}$ in the major producing countries of West Africa [2]. They rank second to cassava as the most important tuber crop in Africa [3]. Out of the over 600 known yam species, the major edible species include Dioscorea rotundata Poir (White yam), Dioscorea cayenensis (Yellow yam), Dioscorea alata (Water yam), Dioscorea bulbifera (Aerial yam), Dioscorea esculenta, Dioscorea praehensalis (Bush yam) and Dioscorea dumetorum (Bitter yam) [1, 4].

Starch is one of the most important natural organic compounds, found in the roots or fruits of plants. The most common sources of food starch for the industries are corn, potato, wheat, tapioca (cassava) and rice [5, 6]. Developed countries (Canada, USA, Europe and Japan) contribute $77 \%$ of the global starch [5]. The food sector consumes $55 \%$ of world production while the remaining $45 \%$ are used in board industries, textile, adhesive, glue and pharmaceutical products [7]. In foods, starch is used to control such characteristics as aesthetics, moisture, consistency and shelf stability. It can be used to bind, expand, densify, clarify or opacify, attract or inhibit moisture. It is also used for different textures such as stringy texture, smooth texture or pulpy texture, soft or crisp coatings, and to stabilize emulsions [5]. Starch and its derivatives are important class of excipients in tablet and capsule formulation [6]. They have excellent properties of compressibility, good binding functionality, powder crystallinity, flowability, acceptable moisture content and desired particle size distribution for favourable mixing conditions with drug [8]. Starches may be used as disintegrants, fillers, glidants (or lubricants) in powder form or as binders in the paste form. The main carbohydrate in yam reserves is starch [9]. Starch in yam tubers account for about $85 \%$ of the dry weight matter, which exist as granules of linear amylose (10-30\%) and highly branched amylopectin (70-90\%) molecules [6].

Sugars are present in minute quantities in yam tubers. Ketiku and Oyenuga [10] observed that the highest total sugar concentration in yam tubers was only $2 \%$, which was attained 4 months after planting. At final harvesting, they recorded less than $1 \%$. Sucrose was observed as the main sugar, most of which were concentrated at the tail (bottom) end of the tuber. Freshly harvested yam tubers have been reported to have lower free sugar levels than stored yams [11-13], these are suspected to be brought about by the breakdown and subsequent hydrolysis of starches into sugars after harvesting. The increase in sugar levels of stored yam gives a more desirable eating quality.

The non-starchy (dietary fibre) components of plants comprise cellulose, lignin, hemicellulose and pectin. They are generally present in the cell wall and have been

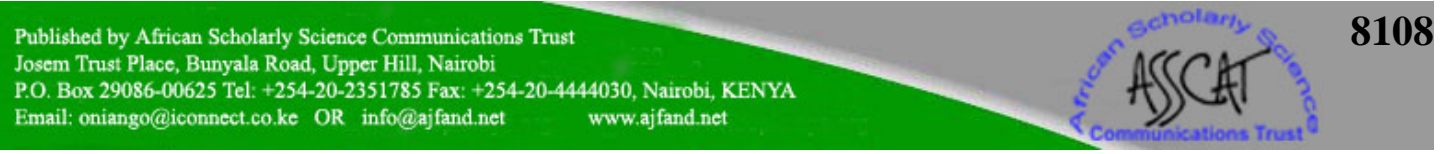




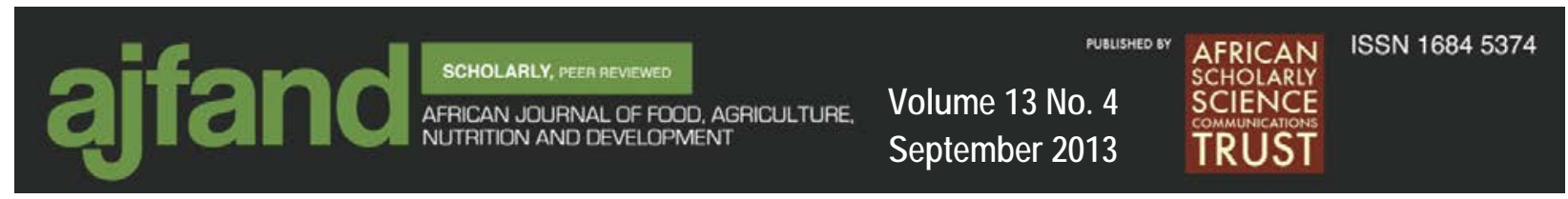

found to have numerous benefits for health and in food product and process development [14]. The cell wall is known to provide rigidity, strength and shape to the plant cell and the non-starchy component of it is partly responsible for the textural properties of the plant-based food. Cellulose has been used as a bulking agent in food due to its water-absorbing ability and low solubility. Both soluble and insoluble hemicelluloses play important roles in food products as soluble and insoluble fibre [15]. Any variations in sugars, starches and the cell wall constituents might have significant influences in their use in both food and industrial processing applications. Thus, the objective of this study was to characterize the relative biochemical compositions and cell wall constituents the different yam species within the Ghanaian yam germplasm, and to assess their potential alternative food and industrial processing applications.

\section{MATERIAL AND METHODS}

\section{Materials and Sample Preparation}

Seven cultivated Dioscorea species grown under the same climatic and edaphic factors were harvested randomly from the Council for Scientific and Industrial Research-Plant Genetic Resources Research Institute, Bunso in the Eastern region of Ghana for laboratory studies. The samples were white yam (Dioscorea rotundata), yellow yam (D. cayenensis), water yam (D. alata), Chinese yam (D. esculenta), aerial yam (D. bulbifera), trifoliate yam (D. dumentorum) and bush yam (D. praehensalis). The samples were cleaned by brushing off soil particles and transported at tropical ambient temperature $\left(28-31^{\circ} \mathrm{C}\right)$ to the laboratory for analysis. In the laboratory, the samples were washed thoroughly with water, peeled, cut into slices of 1.0 by $1.0 \mathrm{~cm}$ using a hand slicer. The slices were then dried at $70{ }^{\circ} \mathrm{C}$ using an air oven. The dried samples were grounded in a Hammer mill (Christy and Norris Ltd, Model 2A, Chelmsford, Surrey, England) into flour to pass through a $250 \mu \mathrm{m}$ mesh size. Flour samples were bagged in sealed transparent polythene (stomacher) bags which were properly labelled and stored in the cold room $\left(4-10^{\circ} \mathrm{C}\right)$, and $\mathrm{RH}$ of $85-90 \%$.

\section{Determination of biochemical compositions}

\section{Starch Determination}

The starch content was determined by the acid hydrolysis method described by Association of Official Analytical Chemists' Approved method 14.023 [16], as modified by Bainbridge et al. [17].

\section{Determination of Amylose content}

The iodo-colorimetric assay method of Sowbhagya and Bhattacharya [18] with some modifications as outlined below was used in the amylose determination: One (1) $\mathrm{ml}$ of absolute ethanol (95\%) was added to $100 \mathrm{mg}$ of the powdered sample in a $100 \mathrm{ml}$ volumetric flask, followed by the addition of $10 \mathrm{ml}$ of $1 \mathrm{~N} \mathrm{NaOH}$. The mixture was kept undisturbed at room temperature overnight. The volume of the mixture was made to $100 \mathrm{ml}$. To $2.5 \mathrm{ml}$ of the extract were added $20 \mathrm{ml}$ of distilled water and three drops

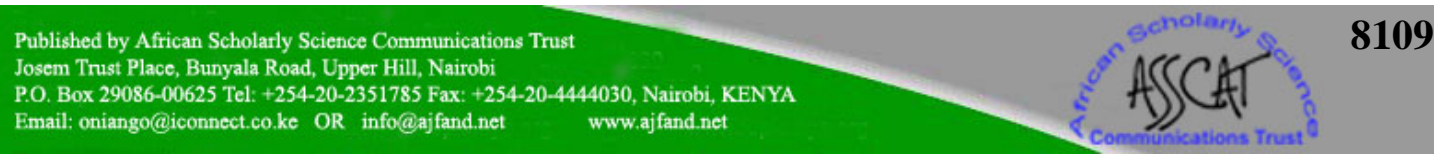


of phenolphthalein in a $50 \mathrm{ml}$ volumetric flask. This was followed by drops of $0.1 \mathrm{~N}$ $\mathrm{HCl}$ until the pink colour just disappeared. One (1) ml of iodine reagent (prepared by dissolving $1 \mathrm{~g}$ iodine crystals and $10 \mathrm{~g}$ Potassium iodide in distilled water made up to $500 \mathrm{ml}$ ) was added and made to $50 \mathrm{ml}$. The absorbance was read at $590 \mathrm{~nm}$. A standard was prepared with $100 \mathrm{mg}$ of pure potato amylose dissolved in $10 \mathrm{ml} 1 \mathrm{~N}$ $\mathrm{NaOH}$ and made to $100 \mathrm{ml}$ with distilled water. Series of 0.1, 0.5, 1.0, 1.5 and $2.0 \mathrm{ml}$ were pipetted into separate $50 \mathrm{ml}$ volumetric flask and the colour was developed as in the case of the sample. A blank was prepared with $1 \mathrm{ml}$ iodine reagent diluted to 50 $\mathrm{ml}$.

\section{Determination of Amylopectin content}

The amount of amylopectin was obtained by subtracting the amylose content from that of starch.

\section{Determination Total Sugars}

Total sugars were determined by the method described by Lane and Eynon [19]. Ten (10) grams of the fine flour sample dissolved in $100 \mathrm{ml}$ of distilled water was mixed with $10 \mathrm{ml}$ concentrated $\mathrm{HCl}$ and the mixture was heated in a water bath for 10 minutes. The solution was then neutralized with $10 \mathrm{ml} \mathrm{NaOH}$, made up to $200 \mathrm{ml}$ with distilled water and filtered. $10 \mathrm{ml}$ mixed Fehling's solution was placed in a conical flask followed by $15 \mathrm{ml}$ of the prepared solution. The solution was heated and on boiling, three drops of methylene blue was added. Further quantities of the solution were added from the burette ( $1 \mathrm{ml}$ at a time) at 10-15 seconds interval to the boiling liquid until the indicator was completely decolourized. The titre values obtained correspond to mg of invert sugar per $100 \mathrm{ml}$.

\section{Determination of Reducing and Non-reducing Sugars}

Reducing sugars were determined by the procedure outlined by Lane and Eynon [19]. About 20-25 g of the flour sample was dissolved in $150 \mathrm{ml}$ of distilled water. The solution was made up to $200 \mathrm{ml}$ and filtered. Ten (10) ml mixed Fehling's solution was placed in a conical flask followed by $15 \mathrm{ml}$ of the prepared solution. The solution was heated and on boiling, three drops of methylene blue was added. Further quantities of the solution were added from the burette ( $1 \mathrm{ml}$ at a time) at $10-15$ seconds interval to the boiling liquid until the indicator was completely decolourized. The titre values obtained correspond to $\mathrm{mg}$ of invert sugar per $100 \mathrm{ml}$. The content of non-reducing sugars was estimated as the difference between the total sugars and reducing sugars while sucrose content was estimated by multiplying the content of non-reducing sugars by the factor 0.95 .

\section{Determination of Cell Wall Constituents}

The cell wall constituents were determined according to the Van Soest fibre analysis principle [14]. The concept behind the detergent fibre analysis is that plant cells can be divided into less digestible cell walls (containing hemicellulose, cellulose and lignin) and mostly digestible cell contents (containing starch and sugars). Van Soest [14] separated these two components successfully by the use of two detergents: a

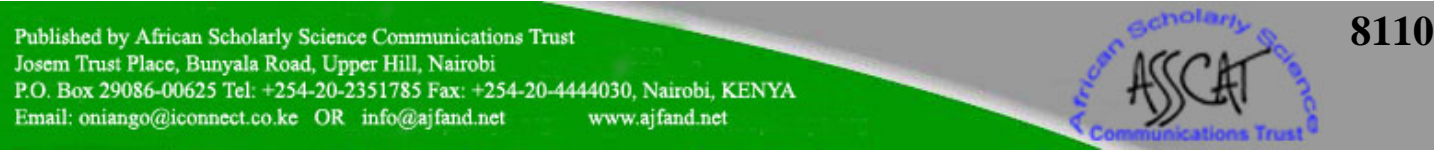




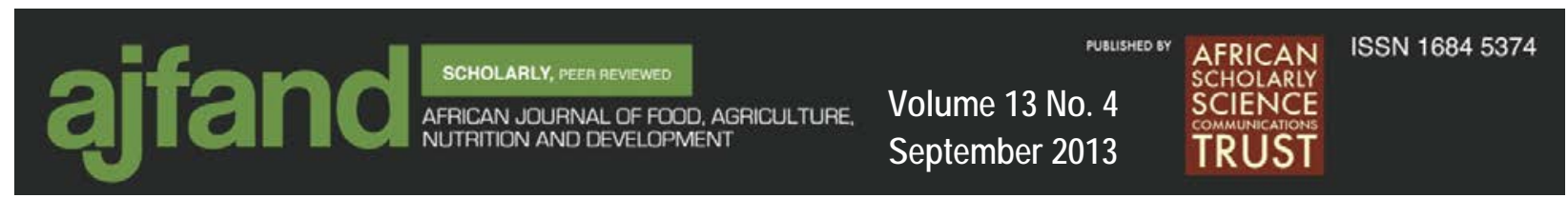

neutral detergent (Na-lauryl sulphate, EDTA, $\mathrm{pH}=7.0$ ) and an acid detergent (cetyltrimethylammonium bromide in $1 \mathrm{~N} \mathrm{H}_{2} \mathrm{SO}_{4}$ ). Neutral Detergent Fibre is a good indicator of "bulk" and thus feed intake while acid detergent fibre is a good indicator of digestibility and thus energy intake.

\section{Acid Detergent Fibre Determination}

The procedure outlined by Van Soest and Wine [20] was used with slight modifications. One $(1) \mathrm{g}$ of the dry finely ground sample $(250 \mu \mathrm{m})$ was weighed into a $100 \mathrm{ml}$ round-bottom flask. Then $100 \mathrm{ml}$ of acid detergent solution at room temperature was added to the sample and then heated gently to boiling and refluxed for 60 minutes from onset of boiling. (The acid detergent solution was prepared by dissolving $20 \mathrm{~g}$ of cetyltrimethylammonium bromide technical grade $\left(\mathrm{C}_{19} \mathrm{H}_{42} \mathrm{BrN}\right)$ in one litre sulphuric acid $1 \mathrm{~N}\left(\mathrm{H}_{2} \mathrm{SO}_{4}, 49.04 \mathrm{~g} / \mathrm{l}\right)$ while stirring and heating gently to promote dissolution. The mixture was allowed to cool to room temperature, $28-30^{\circ} \mathrm{C}$ ). The hot acid detergent treated mixture was poured gently into a porcelain funnel containing a pre-weighed Whatman no. 4 ashless filter paper and drained by applying suction. The insoluble matter in the flask and funnel were washed three times with boiling distilled water and then twice with cold acetone. The insoluble matter was dried overnight at $105^{\circ} \mathrm{C}$, cooled in a desiccator and weighed.

\section{Neutral Detergent Fibre}

The procedure outlined by Van Soest and Wine [20] was used with slight modifications. One (1) g of the dry finely ground sample $(250 \mu \mathrm{m})$ was weighed into a $100 \mathrm{ml}$ round-bottom flask. Then $100 \mathrm{ml}$ of neutral detergent solution at room temperature was added with $0.5 \mathrm{~g}$ of sodium sulphite. \{The neutral detergent solution was prepared by dissolving $6.81 \mathrm{~g}$ of sodium borate decahydrate (Borax, $\mathrm{Na}_{2} \mathrm{~B}_{4} \mathrm{O}_{7} .10 \mathrm{H}_{2} \mathrm{O}$ ), $18.61 \mathrm{~g}$ disodium ethylenediaminetetraacetate (EDTA, $\left.\mathrm{C}_{10} \mathrm{H}_{14} \mathrm{~N}_{2} \mathrm{Na}_{2} \mathrm{O}_{8}\right), 30 \mathrm{~g}$ sodium lauryl sulphate neutral $\left(\mathrm{C}_{10} \mathrm{H}_{25} \mathrm{NaO}_{4} \mathrm{~S}\right), 10 \mathrm{ml} 2-$ ethoxyethanol (ethylene glycol monoethyl ether, cellosolve, $\mathrm{C}_{4} \mathrm{H}_{10} \mathrm{O}_{2}$ ) and $4.56 \mathrm{~g}$ disodium phosphate anhydrous $\left(\mathrm{Na}_{2} \mathrm{HPO}_{4}\right)$ in distilled water while stirring and heating until complete solution was obtained. The solution was made up to one litre with distilled water and the $\mathrm{pH}$ was adjusted to be between 6.9 and 7.1\}. The mixture was heated gently to boiling and refluxed for 60 minutes from onset of boiling. The hot mixture was poured gently into a porcelain funnel containing a pre-weighed Whatman no.4 ashless filter paper and drained by applying suction. The insoluble matter in the flask and funnel were washed three times with boiling distilled water and then twice with cold acetone. The insoluble matter was dried overnight at $105^{\circ} \mathrm{C}$, cooled in a desiccator and weighed.

\section{Hemicelluloses Determination}

The hemicellulose content was estimated as the difference between neutral detergent fibre and acid detergent fibre [14].

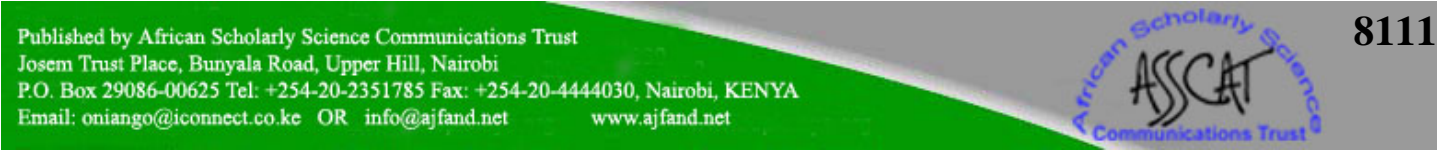




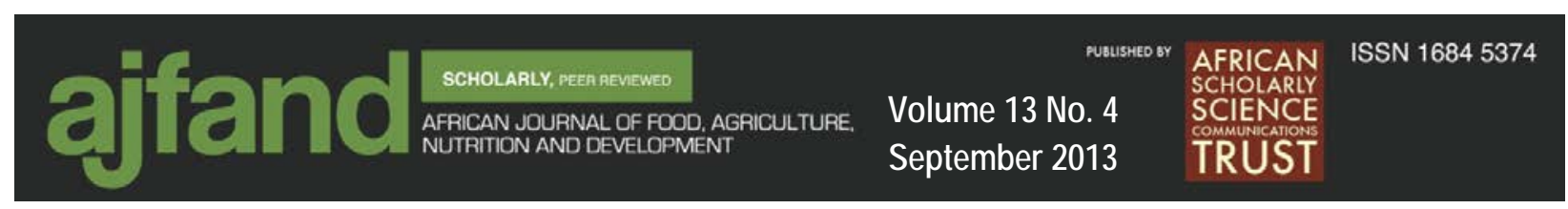

\section{Cellulose}

The cellulose content was determined according to the method described by Updegroff [21]. Cellulose undergoes acetolysis with acetic/nitric reagent forming acetylated cellodextrins which get dissolved and hydrolyzed to form glucose molecules on treatment with $67 \% \mathrm{H}_{2} \mathrm{SO}_{4}$. This glucose molecule is dehydrated to form hydroxymethyl furfural which forms green coloured product with anthrone and the colour intensity is measured at $630 \mathrm{~nm}$ using spectrophotometer (Lambda-45 Perkin Elmer, Shelton CT 06484, USA).

Three (3) $\mathrm{ml}$ of acetic/nitric reagent (prepared by mixing $150 \mathrm{ml}$ of $80 \%$ acetic acid and $15 \mathrm{ml}$ of concentrated nitric acid) was added to one (1) $\mathrm{g}$ of the fine flour in a test tube and mixed thoroughly in a vortex mixer. The tubes were placed in a boiling water bath for 30 minutes. The mixture was allowed to cool and then centrifuged for 20 minutes at $3000 \mathrm{rev}$. The supernatant was discarded while the residue was washed with distilled water. $10 \mathrm{ml}$ of $67 \%$ sulphuric acid was added to the tube and allowed to stand for 1 hour. $1 \mathrm{ml}$ of the above solution was diluted to $100 \mathrm{ml}$ with distilled water. $10 \mathrm{ml}$ of anthrone reagent was added to $1 \mathrm{ml}$ of this diluted solution and mixed well. (The anthrone reagent was prepared by dissolving $200 \mathrm{mg}$ anthrone in $100 \mathrm{ml}$ concentrated sulphuric acid. This was prepared fresh and chilled for 2 hours before use). The tube and its contents were heated in a boiling water-bath for 10 minutes. It was allowed to cool and the intensity of the colour was measured at $630 \mathrm{~nm}$. A blank was prepared with $1 \mathrm{ml}$ distilled water and $10 \mathrm{ml}$ anthrone reagent. A standard stock solution was prepared with $100 \mathrm{mg}$ of cellulose mixed with $10 \mathrm{ml}$ of $67 \%$ sulphuric acid in a test tube and the colour was developed as in the case of the sample using a series of volumes $0.5-3.5 \mathrm{ml}$ corresponding to $50-350 \mu \mathrm{g}$ of cellulose.

\section{Acid Detergent Lignin}

The acid detergent lignin content was estimated as the difference between the cellulose and acid detergent fibre contents [14].

\section{Statistical analysis}

Statgraphics (Centurion version) and Minitab (version 14) were used for multivariate analysis and graphical presentation of data. Analysis of variance (ANOVA) was used to test for significant differences between means. A multiple range test (Tukey's Least Significant Difference) was conducted at a level of significance of $\mathrm{p}<0.05$. Cluster analysis (cluster observation) was carried out to determine yam varieties with similar characteristics. Principal component analysis was used to determine any patterns and explore the relationships between the various parameters and the yam varieties. 


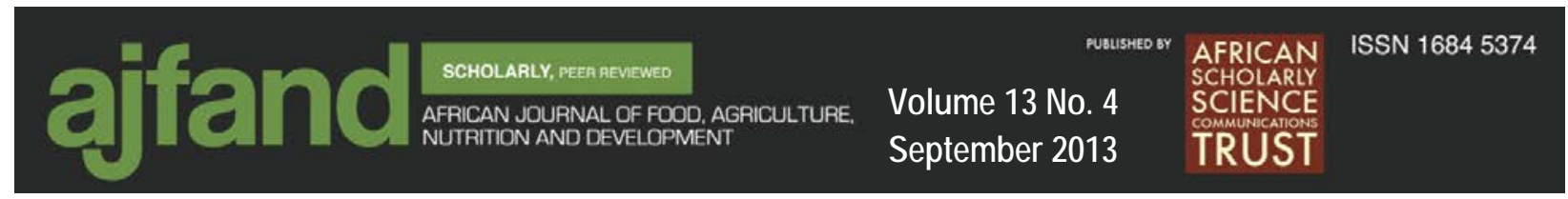

\section{RESULTS}

\section{Biochemical composition}

Starch content of yam varieties

Variations in the starch content along the length of each tuber were not significantly different at $\mathrm{p}<0.05$ (Table 1 ). The lowest starch content was detected in $D$. dumetorum with $56.90 \%$ at the tail end, $58.26 \%$ at the middle portion and $59.14 \%$ at the head region. $D$. cayenensis recorded the highest starch content of $63.16 \%$ at the tail end, $64.03 \%$ at the middle portion and $65.69 \%$ at the head region. The tail end of $D$. rotundata was observed to contain highest starch in all the varieties analyzed. The trend of starch concentration was the same along each of the varieties considered except $D$. alata which had highest starch at the middle section (Tail: 63.24\%, Middle: 65.17\% and Head: 64.61\%). Similar trend was reported by Ketiku and Oyenuga [10] with starch contents of $61.52 \%$ at the tail, $77.28 \%$ at the middle portion and $77.57 \%$ at the head region.

Amylose content was observed to range from 9.22\%, 9.58\% and $10.39 \%$ for $D$. esculenta to $19.53 \%, 17.45 \%$ and $21.66 \%$ for $D$. rotundata along the tail, middle and head sections respectively (Table 1). Amylose values of $18.3 \%, 17.1 \%$ and $18.8 \%$ for tail, middle and head have been reported by Ketiku and Oyenuga [10]. No identifiable trend was observed for the amylopectin content along the length between the varieties investigated. D. bulbifera recorded the lowest amylopectin content of $41.29 \%$, $43.59 \%$ and $44.63 \%$ while D. esculenta had the highest with $49.84 \%, 50.24 \%$ and $50.13 \%$ along the tail, middle and head sections respectively.

\section{Free sugars in yam varieties}

Total sugar content in the yam varieties varied significantly $(\mathrm{p}<0.05)$ from $2.58 \%$, $2.16 \%$ and $2.18 \%$ in D. cayenensis to $4.84 \%, 4.74$ and $4.82 \%$ in D. bulbifera at the tail, middle and head regions respectively (Table 2). The total sugar at the tail portions for all the varieties studied was higher than the head regions; the middle portions recorded the least. This trend agrees with the results obtained by other researchers elsewhere [10,13]. Reducing sugars were only about $1 \%$ while sucrose content ranged from $1.36 \%, 1.11 \%$ and $1.15 \%$ in $D$. cayenensis to $3.61 \%, 3.64 \%$ and $3.58 \%$ in $D$. bulbifera at the tail, middle and head sections. In all, the sucrose content represented 51.4 to $76.8 \%$ of the total sugar in the studied varieties. These values compare well with the $1.20 \%, 0.78 \%$ and $0.72 \%$ for reducing sugar; $3.32 \%, 0.96 \%$ and $1.63 \%$ for sucrose (representing $53-68 \%$ of total sugar) at the tail, middle and head portions, respectively, reported by Ketiku and Oyenuga [10]. There were no significant differences in the sugars along the length of each of the varieties examined.

\section{Cell Wall Constituents}

There were variations in the cell wall constituents of the yam varieties that were studied. Neutral detergent fibre found in this study ranged from $1.18 \mathrm{~g} / 100 \mathrm{~g}$ in $D$. alata to $5.46 \mathrm{~g} / 100 \mathrm{~g}$ in $D$. esculenta. The range compares favourably with the $1.34-$

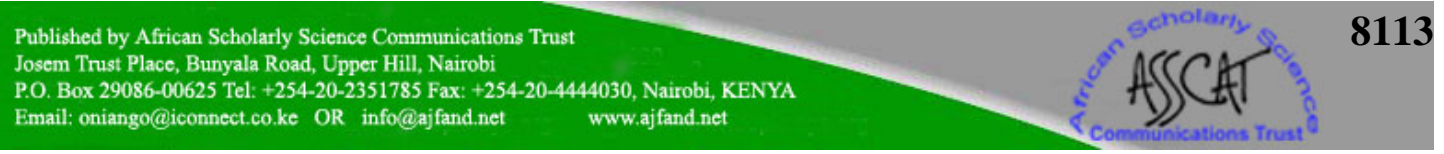




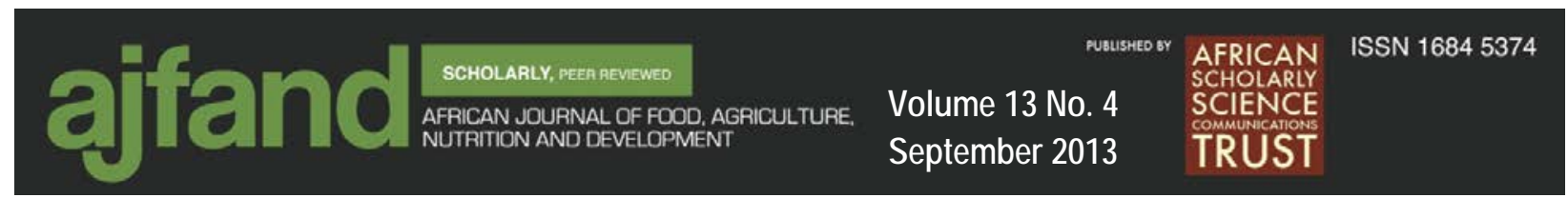

2.57\% in four Nigerian yams as reported by Abara et al. [15] and with the $1.6-8.6$ $\mathrm{g} / 100 \mathrm{~g}$ found in Cameroonian yams by Agbor-Egbe and Treche [22]. There were significant differences $(\mathrm{p}<0.05)$ in the values of neutral detergent fibre found in Dioscorea esculenta and the other yam species (Table 3).

Acid detergent fibre was the least component in the varieties analyzed; the highest recorded was $0.89 \mathrm{~g} / 100 \mathrm{~g}$ in $D$. esculenta while $D$. bulbifera had as low as 0.11 g/100g. These values fell below the $1.2-7.6 \%, 11.34-13.75 \%$ and $1.13-2.30 \%$ detected by earlier researchers [15, 22, 23]. Lignin content ranged from $1.56 \mathrm{~g} / 100 \mathrm{~g}$ in $D$. dumetorum to $2.87 \mathrm{~g} / 100 \mathrm{~g}$ for $D$. praehensalis relative to the $5.34-5.89 \%$ and the $0.08-0.27 \%$ reported by Afoakwa and Sefa-Dedeh [23] and Abara et al. [15], respectively. There was no significant difference among yam varieties in the $2.41-$ $3.53 \mathrm{~g} / 100 \mathrm{~g}$ cellulose content. These values agreed with the 2.33 - 3.04\% reported by Ketiku and Oyenuga [10] but lower than the 17.10 - 19.73\% reported by Afoakwa and Sefa-Dedeh [23] and higher than the $0.80-1.13 \%$ by Abara et al. [15]. Hemicellulose was low in D. alata $(0.42 \mathrm{~g} / 100 \mathrm{~g})$ and highest in D. esculenta (4.58 $\mathrm{g} / 100 \mathrm{~g}$ ) which is comparable to the $1.22-1.85 \%$ discovered by Ketiku and Oyenuga [10] but lower than $0.15-0.27 \%$ Abara et al. [15].

\section{DISCUSSION}

Starch is the most significant form of carbon reserve in plants in terms of the amount made, the universality of its distribution among different plant species, and its commercial importance. In yams, starch is produced in the leaves which accumulates in the tuber and becomes converted to sugars when the tissues require energy for respiration. Variability in biochemical composition and cell wall constituents of yams grown in the same environment with the same quantity, quality and duration of light, temperature and carbon (IV) oxide concentration can be attributed to differences in genetic constituents of the yam varieties. The starch, amylase and amylopectic concentrations along the length of each tuber of the yam varieties investigated are summarized in Table 1.

\section{Cluster and principal component analysis for biochemical characteristics of yam varieties}

Cluster observation analysis was conducted to group yam varieties based on similarities in their biochemical characteristics; patterns and interrelationships between the samples and the characteristics were also displayed using principal component analysis. The cluster observation dendogram for the starch and sugars in the yam varieties investigated is shown in Figure 1. The varieties were divided into five clusters based on similarity of starch and sugar composition.

The dendogram shows that differences do exist in the samples on the basis of their biochemical characteristics. D. rotundata and D. alata in the first cluster are similar; $D$. cayenensis and D. praehensalis in the second cluster are also similar while each of

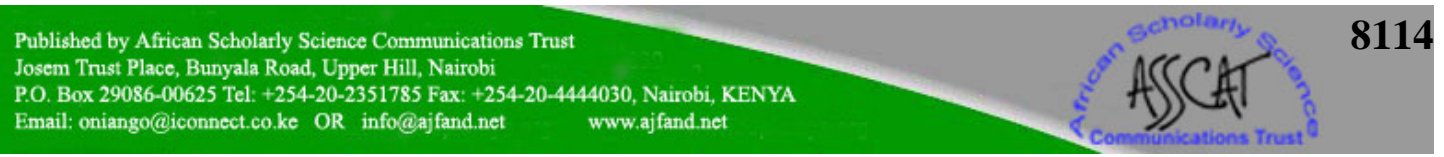




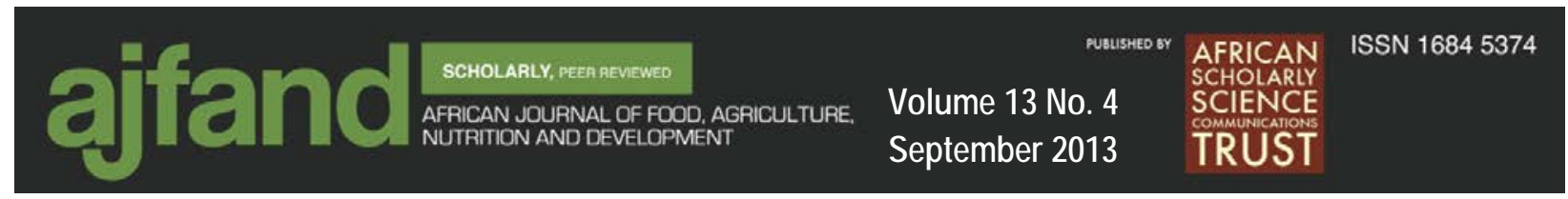

D. dumetorum, D. bulbifera and D. esculenta has separate biochemical compositions that make them to differ one from the other.

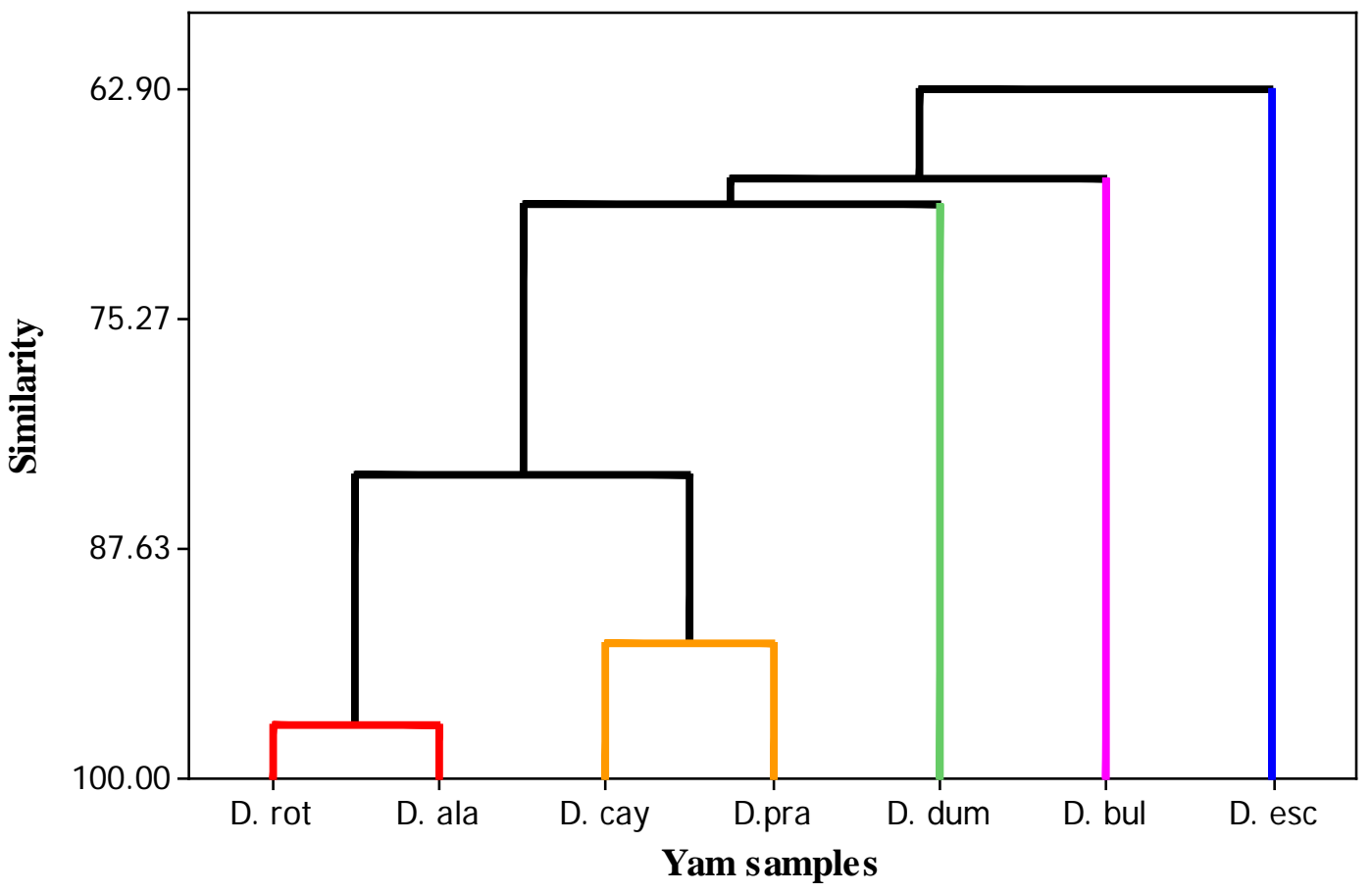

Figure 1: Cluster observation dendogram for biochemical characteristics of yam varieties

KEY: D. $\operatorname{rot}=D$. rotundata, $\mathbf{D}$. ala $=D$. alata, $\mathbf{D}$. cay $=D$. cayenensis, $\mathbf{D} . \mathbf{b u l}=D$. bulbifera, $\mathbf{D}$. pra $=$ D. praehensalis, $\mathbf{D} . \mathbf{e s c}=D$. esculenta, $\mathbf{D} . \mathbf{d u m}=D$. dumetorum

A total of two principal components (PC) described $77.4 \%$ of variability in the biochemical characteristics of the yam varieties. PC1 and PC2 accounted for 54.2\% and $23.2 \%$ of the variability respectively (Figure 2). Amylose content, total sugar and sucrose content dominated PC1 while starch and amylopectin content contributed the most to the variation in PC2. The principal component scores plot (Figure 3) revealed that $D$. rotundata and $D$. alata were related by having identical starch content. They loaded to the same positive quadrant of PC1 (Figures 2 and 3). D. cayenensis and D. praehensalis had similar levels of amylose and reducing sugars while $D$. dumetorum, $D$. esculenta and $D$. bulbifera loaded to negative side of PC1 differed by various levels of amylopectin, total sugar and sucrose. D. bulbifera stood out with low amylopectin content but high total sugar and sucrose contents. D. dumetorum on the contrary, recorded high amylopectin with low sugars while $D$. esculenta contain relatively high contents of amylopectin and sugars. 


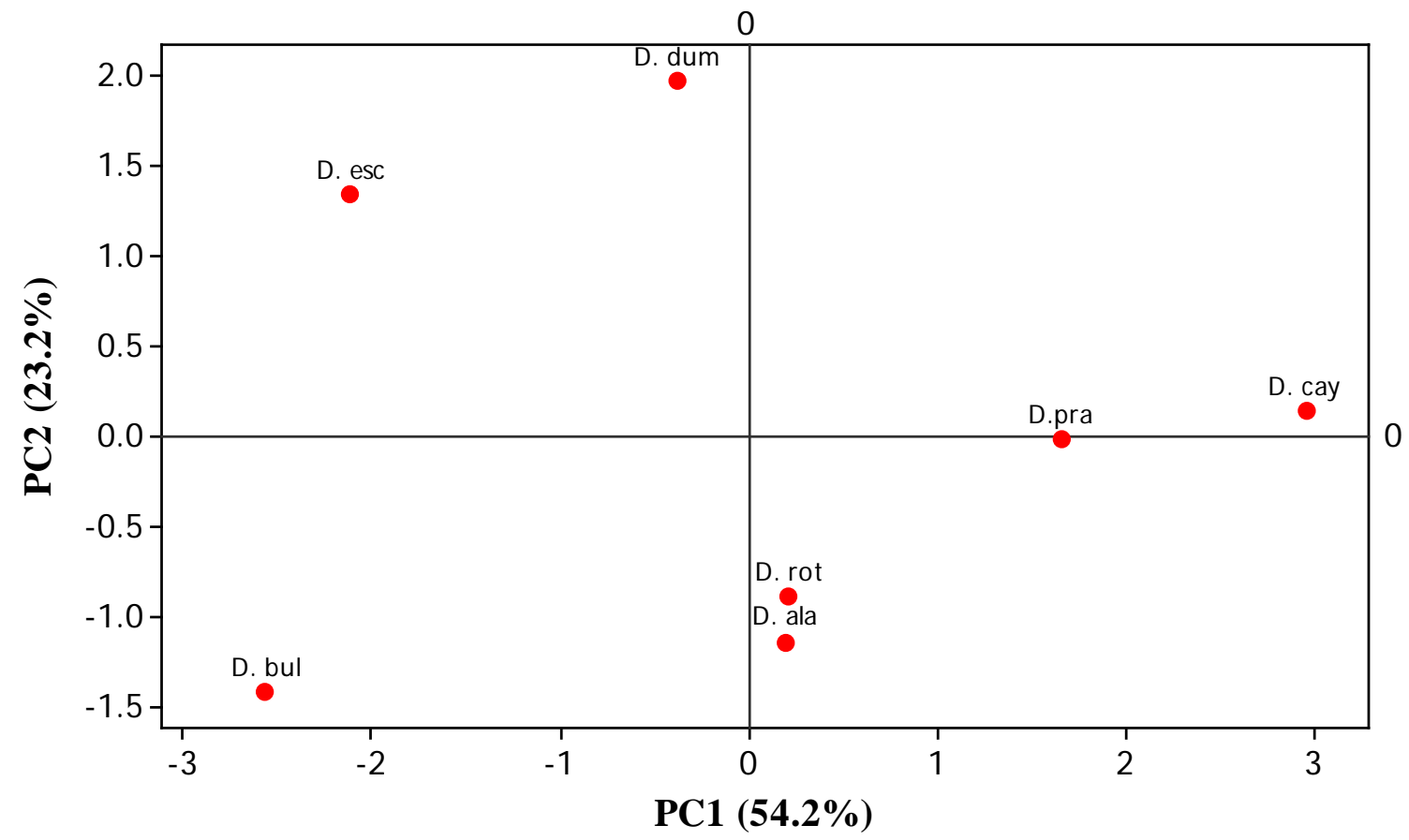

Figure 2: Sample score plot for the principal component analysis of the biochemical characteristics of the yam varieties

KEY: D. $\mathbf{r o t}=D$. rotundata, $\mathbf{D}$. ala $=D$. alata, $\mathbf{D} . \mathbf{c a y}=D$. cayenensis, $\mathbf{D}$. $\mathbf{b u l}=D$. bulbifera, D. pra $=D$. praehensalis, $\mathbf{D} . \mathbf{~ e s c}=D$. esculenta, $\mathbf{D} . \mathbf{d u m}=D$. dumetorum 


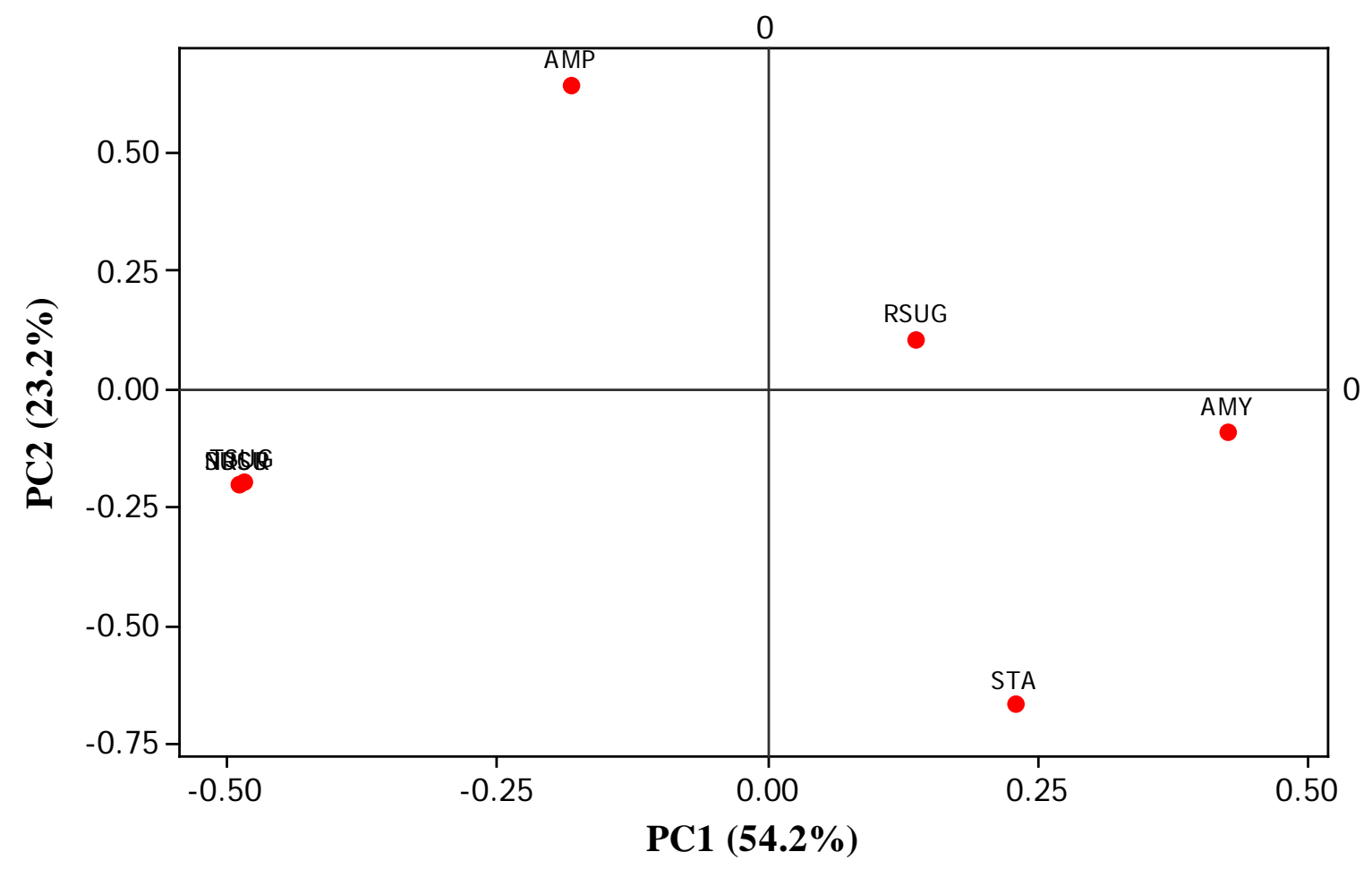

Figure 3: Variable weights plot for the principal component analysis of the biochemical characteristics of the yam varieties

KEY: STA= Starch, AMY = Amylose, $\mathbf{A M P}=$ Amylopectin, $\mathbf{T S U G}=$ Total Sugars, $\widehat{\text { RSUG}}=$ Reducing Sugars, $\mathbf{N R S U}=$ Non-reducing Sugars, $\mathbf{S U C R}=$ Sucrose

Significant differences at $\mathrm{p}<0.05$ existed between the biochemical characteristics of studied yam varieties. D. cayenensis, D. rotundata and $D$. alata had high starch contents and could be used as thickeners to improve or maintain the quality of food products. All the yam varieties, except $D$. dumetorum and $D$. esculenta, contained high contents of amylose. D. bulbifera with high sugar contents would be suitable raw materials for fermentation during industrial production of alcohol and organic acids.

Cluster and principal component analysis for cell wall constituents of yam varieties

Cluster analysis was used to group yam varieties into three clusters (Figure 4) based on similarities of cell wall constituents. D. rotundata, D. praehensalis and $D$. bulbifera form the first cluster; $D$. alata and $D$. cayenensis for the second cluster while $D$. dumetorum and $D$. esculenta constitute the third cluster. 


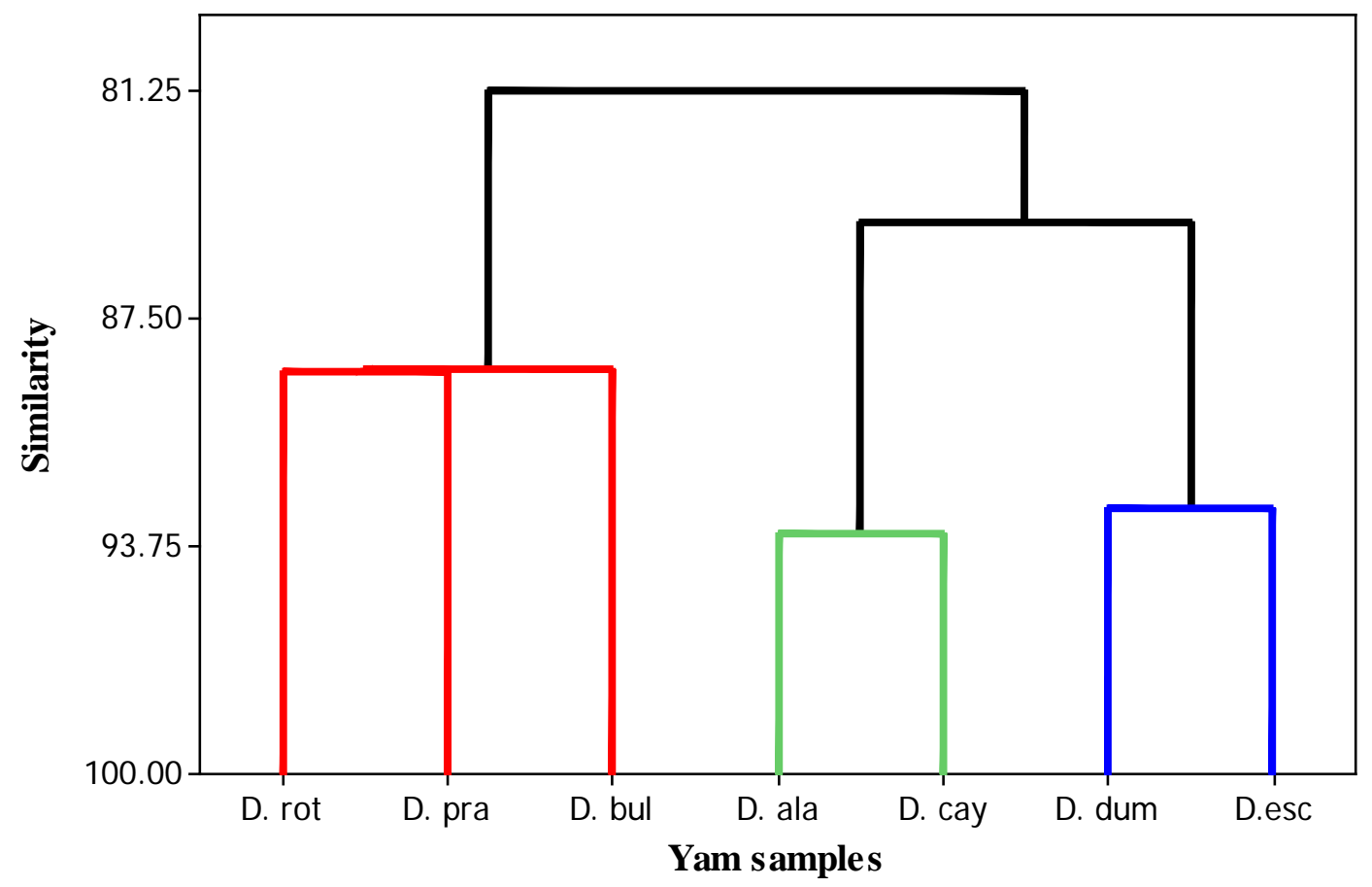

Figure 4: Cluster observation dendogram for cell wall constituents of yam varieties

$\underline{\text { KEY }: ~ D . ~}$ rot $=D$. rotundata, $\mathbf{D}$. ala $=D$. alata, $\mathbf{D}$. cay $=D$. cayenensis, $\mathbf{D} . \mathbf{b u l}=D$. bulbifera, $\mathbf{D} . \mathbf{p r a}=D$. praehensalis, $\mathbf{D} . \mathbf{e s c}=D$. esculenta, $\mathbf{D} . \mathbf{d u m}=D$. Dumetorum

Principal component (PC) analysis explained a total of $94.3 \%$ of the variability in the sample score plot (Figure 5). PC1 explained $64.6 \%$ of the variation while PC2 accounted for $29.7 \%$. The sample score plot confirmed the cluster dendogram by loading varieties with similar characteristics to the same side of PC1 and PC2. The variable weights plot (Figure 6) revealed that, PC1 is strongly influenced by cellulose content and acid detergent fibre, while PC2 is dominated by neutral detergent fibre and hemicellulose. Thus, $D$. rotundata, $D$. praehensalis and $D$. bulbifera (first cluster) were related in their content of high levels of acid detergent lignin and cellulose. $D$. cayenensis and D. alata (second cluster) generally contain low levels of the components, except acid detergent fibre. D. dumetorum and D. esculenta (third cluster) generally contain high levels of the cell wall components, except acid detergent lignin. Whatever variations that were observed between this study and those of other workers might be due to species differences, stage of maturity and growing environment as dietary fibre depends on these factors. 
The results obtained for cell wall components in this study showed that these components are low in yam species generally. However, among the yam species analyzed in this study for dietary fiber components, Dioscorea esculenta and D. dumetorum showed the highest values for the components except in acid detergent lignin content which was found to be highest in Dioscorea rotundata (3.36 g/100g).

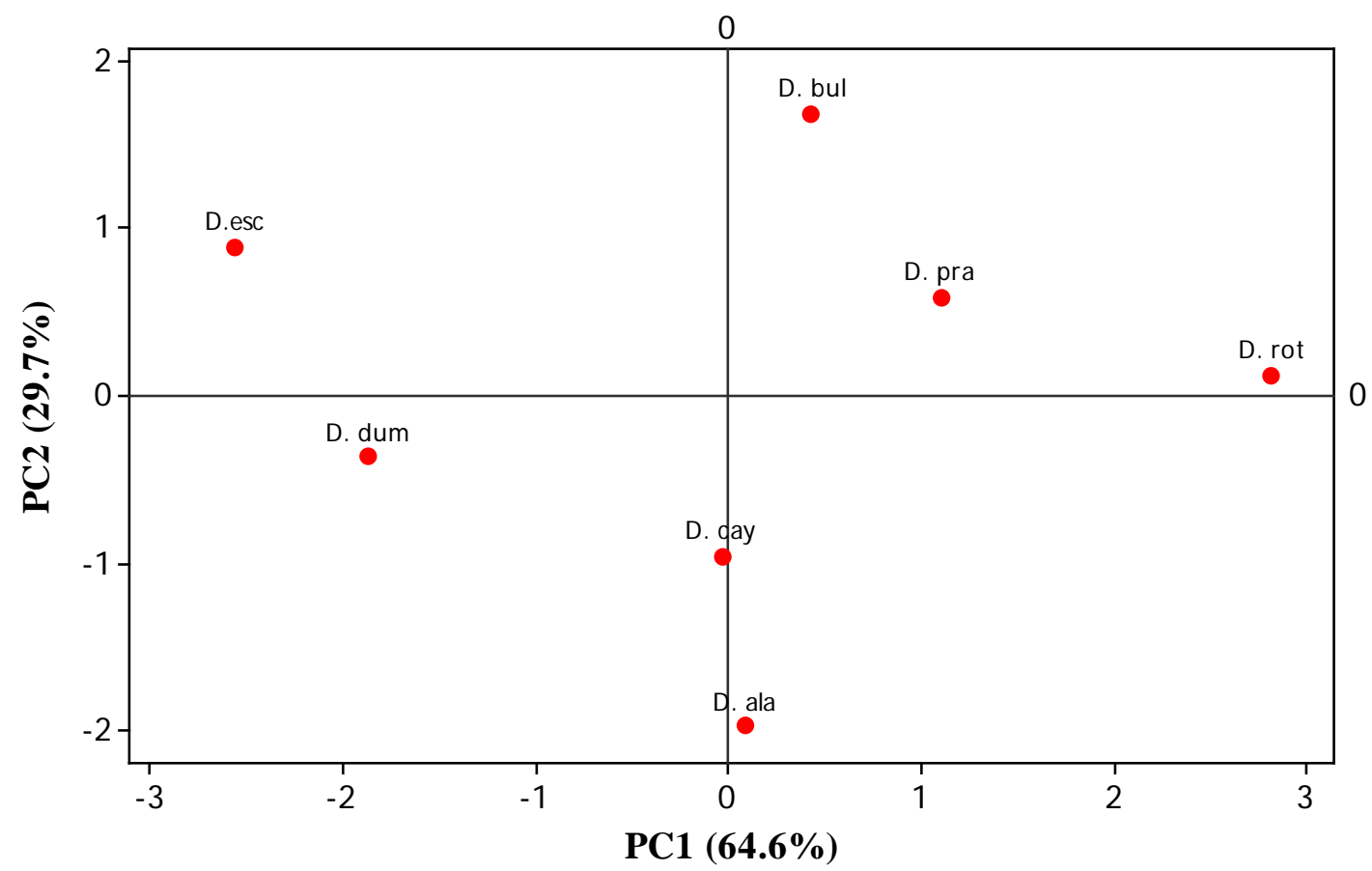

Figure 5: Sample score plot for the principal component analysis of the cell wall characteristics of the yam varieties

KEY: D. $\mathbf{r o t}=D$. rotundata, $\mathbf{D}$. ala $=D$. alata, $\mathbf{D}$. cay $=D$. cayenensis, $\mathbf{D} . \mathbf{b u l}=D$. bulbifera, $\mathbf{D}$. pra $=D$. praehensalis, $\mathbf{D} . \mathbf{e s c}=D$. esculenta, $\mathbf{D} . \mathbf{d u m}=D$. Dumetorum 


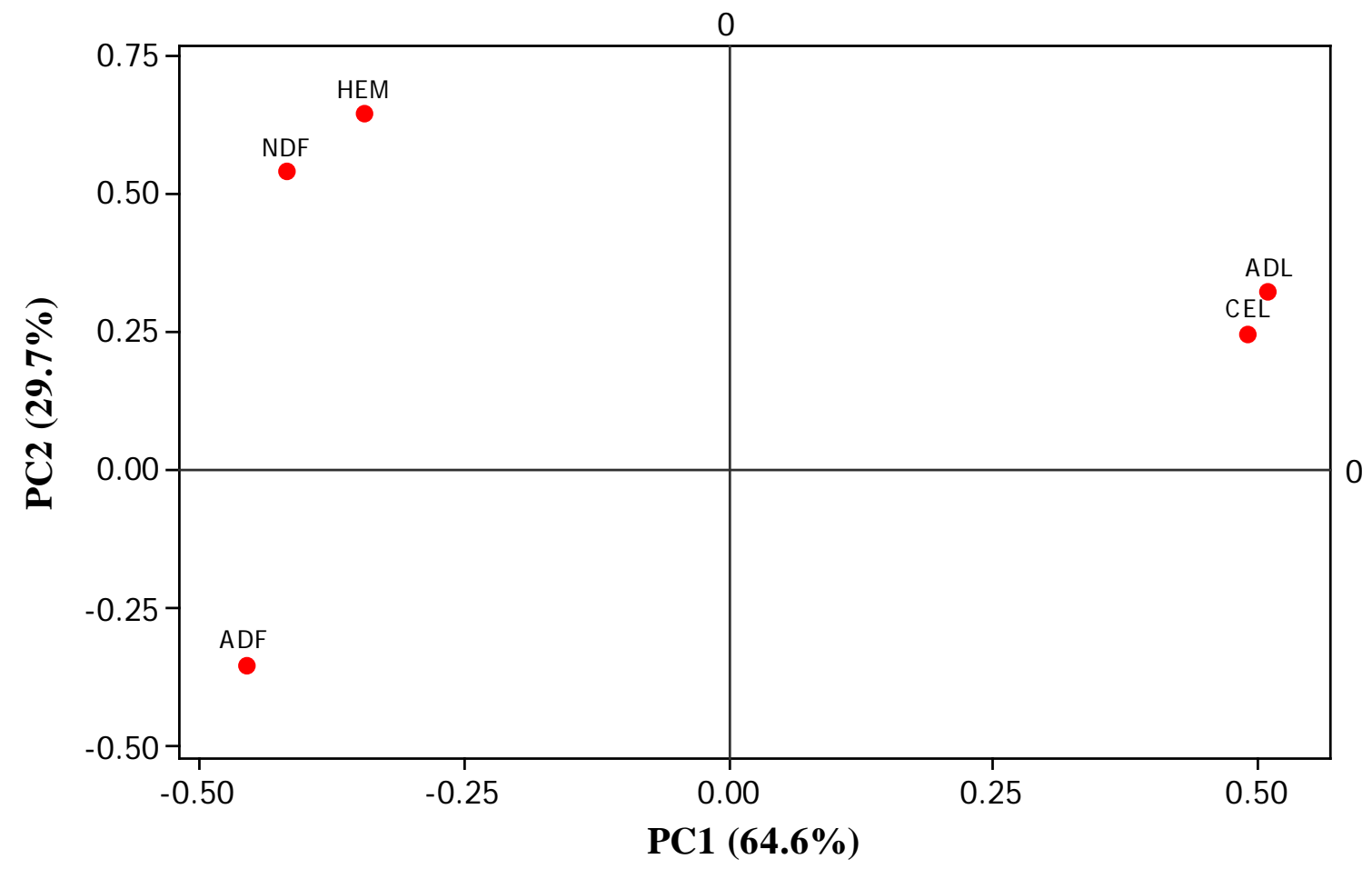

Figure 6: Variable weights plot for the principal component analysis of the cell wall characteristics of the yam varieties

KEY: ADF=Acid Detergent Fibre, NDF $=$ Neutral Detergent Fibre, $\mathbf{A D L}=$ Acid

Detergent Lignin, $\mathbf{H E M}=$ Hemicellulose, $\mathbf{C E L}=$ Cellulose

\section{CONCLUSION}

The biochemical composition and cell wall constituents of the seven different yam (Dioscorea) species grown and consumed in Ghana were significantly different. However, no significant difference was observed along the length of each tuber. $D$. cayenensis (Pure-yellow), D. rotundata (Pona) and D. alata (Matches) were found to have high starch contents (63.16-65.69\%, 63.54-65.30\% and 63.24-65.17\% respectively). D. alata was observed to contain the highest amylose content of 19.6620.64\%. D. bulbifera recorded highest total sugar contents (4.74-4.84\%). Cellulose was found to be the most common cell wall component with $D$. rotundata having the highest level of $3.36 \%$ whilst $D$. dumetorum had the least $(1.56 \%)$. Hemicellulose content ranged between $0.42 \mathrm{~g} / 100 \mathrm{~g}$ in $D$. alata to $4.58 \mathrm{~g} / 100 \mathrm{~g}$ in D. esculenta, and only $<1 \%$ of acid detergent fiber was identified in the yam varieties. These suggest that the different yam varieties have different biochemical and structural characteristics and may be suitable for different food and industrial processing applications. 


\section{ACKNOWLEDGEMENT}

The authors express their gratitude to Dr. Lawrence Abbey, Mr Charles Diako, Mr. Freeman Aidoo, and Mr. Clement Asiedu for technical support. Special thanks also go to the management and workers of the Root and Tuber Conservatory Department of the Council for Scientific and Industrial Research-Plant Genetic Resource Research Institute, Bunso for supplying the yam samples. 
Table 1: Starch content of yam varieties

\begin{tabular}{|c|c|c|c|c|}
\hline Yam variety & $\begin{array}{l}\text { Yam } \\
\text { part }\end{array}$ & $\begin{array}{l}\text { Starch } \\
(\%)\end{array}$ & $\begin{array}{l}\text { Amylose } \\
(\%)\end{array}$ & $\begin{array}{l}\text { Amylopectin } \\
(\%)\end{array}$ \\
\hline D. rotundata & Tail & $63.54 \pm 0.84^{\mathrm{e}, \mathrm{f}}$ & $19.53 \pm 0.19^{\mathrm{e}, \mathrm{f}}$ & $44.01 \pm 0.65^{\mathrm{a}, \mathrm{b}}$ \\
\hline \multirow[t]{2}{*}{ (Pona) } & Middle & $64.89 \pm 0.16^{\mathrm{f}, \mathrm{g}}$ & $17.45 \pm 1.59^{\mathrm{d}}$ & $47.45 \pm 1.75^{\mathrm{c}, \mathrm{d}}$ \\
\hline & Head & $65.30 \pm 0.24^{\mathrm{f}, \mathrm{g}}$ & $21.66 \pm 0.19^{\mathrm{i}}$ & $43.64 \pm 0.43^{\mathrm{a}, \mathrm{b}}$ \\
\hline \multirow[t]{3}{*}{ D. alata (Matches) } & Tail & $63.24 \pm 2.38^{\mathrm{d}, \mathrm{e}}$ & $19.66 \pm 0.14^{\mathrm{e}, \mathrm{f}}$ & $43.58 \pm 2.24^{\mathrm{a}, \mathrm{b}}$ \\
\hline & Middle & $65.17 \pm 0.12^{f, g}$ & $20.17 \pm 0.15^{\mathrm{f}, \mathrm{g}}$ & $45.00 \pm 0.27^{\mathrm{a}, \mathrm{b}}$ \\
\hline & Head & $64.61 \pm 0.18^{\mathrm{f}, \mathrm{g}}$ & $20.64 \pm 0.52^{\mathrm{h}, \mathrm{i}}$ & $43.98 \pm 0.70^{\mathrm{a}, \mathrm{b}}$ \\
\hline D. dumetorum & Tail & $56.90 \pm 0.33^{\mathrm{a}}$ & $9.88 \pm 0.39^{\mathrm{a}, \mathrm{b}}$ & $47.03 \pm 0.72^{\mathrm{b}, \mathrm{c}}$ \\
\hline \multirow[t]{2}{*}{ (Yellow) } & Middle & $58.26 \pm 0.12^{\mathrm{a}, \mathrm{b}}$ & $10.48 \pm 0.34^{\mathrm{a}, \mathrm{b}}$ & $47.78 \pm 0.46^{\mathrm{d}, \mathrm{e}}$ \\
\hline & Head & $59.14 \pm 1.24^{\mathrm{a}, \mathrm{b}}$ & $11.10 \pm 0.01^{b}$ & $48.04 \pm 1.23^{\mathrm{e}, \mathrm{f}}$ \\
\hline D. esculenta & Tail & $59.06 \pm 0.12^{\mathrm{a}, \mathrm{b}}$ & $9.22 \pm 0.15^{\mathrm{a}}$ & $49.84 \pm 0.27^{\mathrm{f}}$ \\
\hline \multirow[t]{2}{*}{ (Large) } & Middle & $59.82 \pm 0.86^{\mathrm{a}, \mathrm{b}}$ & $9.58 \pm 0.13^{\mathrm{a}, \mathrm{b}}$ & $50.24 \pm 0.99^{f}$ \\
\hline & Head & $60.52 \pm 1.77^{\mathrm{b}, \mathrm{c}}$ & $10.39 \pm 0.01^{\mathrm{a}, \mathrm{b}}$ & $50.13 \pm 1.78^{f}$ \\
\hline D. cayenensis & Tail & $63.16 \pm 0.46^{\mathrm{d}, \mathrm{e}}$ & $19.98 \pm 0.15^{\mathrm{f}, \mathrm{g}}$ & $43.19 \pm 0.31^{\mathrm{a}, \mathrm{b}}$ \\
\hline \multirow[t]{2}{*}{ (Pure Yellow) } & Middle & $64.03 \pm 0.22^{\mathrm{f}, \mathrm{g}}$ & $18.57 \pm 0.29^{\mathrm{d}, \mathrm{e}}$ & $45.52 \pm 0.44^{\mathrm{b}, \mathrm{c}}$ \\
\hline & Head & $65.69 \pm 0.73^{g}$ & $20.71 \pm 0.24^{\mathrm{h}, \mathrm{i}}$ & $44.98 \pm 0.97^{\mathrm{a}, \mathrm{b}}$ \\
\hline D. bulbifera & Tail & $59.30 \pm 1.18^{\mathrm{a}, \mathrm{b}}$ & $18.01 \pm 0.15^{\mathrm{d}, \mathrm{e}}$ & $41.29 \pm 1.03^{\mathrm{a}}$ \\
\hline \multirow[t]{2}{*}{ (Deep brown skin) } & Middle & $63.77 \pm 0.87^{\mathrm{e}, \mathrm{f}}$ & $20.17 \pm 0.15^{\mathrm{f}, \mathrm{g}}$ & $43.59 \pm 1.02^{\mathrm{a}, \mathrm{b}}$ \\
\hline & Head & $65.04 \pm 0.10^{\mathrm{t}, \mathrm{g}}$ & $20.41 \pm 0.20^{\mathrm{g}, \mathrm{h}}$ & $44.63 \pm 0.11^{\mathrm{a}, \mathrm{b}}$ \\
\hline \multirow[t]{3}{*}{ D. praehensalis } & Tail & $62.11 \pm 0.09^{\mathrm{c}, \mathrm{d}}$ & $15.42 \pm 0.19^{\mathrm{C}}$ & $46.70 \pm 0.11^{\mathrm{b}, \mathrm{c}}$ \\
\hline & Middle & $62.51 \pm 0.02^{\mathrm{c}, \mathrm{d}}$ & $18.82 \pm 0.39^{\mathrm{d}, \mathrm{e}}$ & $43.69 \pm 0.40^{\mathrm{a}, \mathrm{b}}$ \\
\hline & Head & $62.99 \pm 0.53^{\mathrm{d}, \mathrm{e}}$ & $21.41 \pm 0.09^{\mathrm{i}}$ & $41.58 \pm 0.62^{\mathrm{a}}$ \\
\hline
\end{tabular}

Values are Means \pm standard deviation from duplicate analyses. Those with the same superscripts in the same column are not significantly different at $\mathrm{P}<0.05$ 


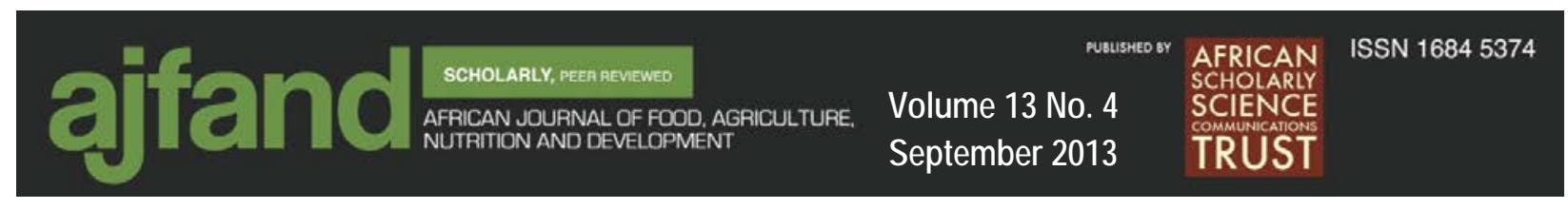

Table 2: Free sugars in yam varieties

\begin{tabular}{|c|c|c|c|c|c|}
\hline Yam variety & Yam part & $\begin{array}{c}\text { Total Sugars } \\
(\%)\end{array}$ & $\begin{array}{c}\text { Reducing Sugars } \\
(\%)\end{array}$ & $\begin{array}{c}\text { Non-Reducing } \\
\text { Sugars (\%) }\end{array}$ & $\begin{array}{c}\text { Sucrose } \\
(\%)\end{array}$ \\
\hline \multirow[t]{3}{*}{ D. rotundata (Pona) } & Tail & $4.39 \pm 0.03^{h, i}$ & $1.12 \pm 0.02^{\mathrm{d}, \mathrm{e}}$ & $3.16 \pm 0.05^{\mathrm{g}, \mathrm{h}}$ & $3.00 \pm 0.04^{\mathrm{g}, \mathrm{h}}$ \\
\hline & Middle & $3.74 \pm 0.10^{\mathrm{d}, \mathrm{e}}$ & $1.11 \pm 0.00^{\mathrm{d}, \mathrm{e}}$ & $2.63 \pm 0.10^{\mathrm{c}, \mathrm{d}}$ & $2.49 \pm 0.10^{\mathrm{c}, \mathrm{d}}$ \\
\hline & Head & $4.00 \pm 0.10^{\mathrm{f}, \mathrm{g}}$ & $1.04 \pm 0.06^{\mathrm{c}, \mathrm{d}}$ & $2.96 \pm 0.04^{\mathrm{e}, \mathrm{f}}$ & $2.81 \pm 0.04^{\mathrm{e}, \mathrm{f}}$ \\
\hline \multirow[t]{3}{*}{ D. alata (Matches) } & Tail & $4.06 \pm 0.01^{\mathrm{g}, \mathrm{h}}$ & $1.10 \pm 0.02^{\mathrm{d}, \mathrm{e}}$ & $2.96 \pm 0.03^{\mathrm{e}, \mathrm{f}}$ & $2.81 \pm 0.03^{\mathrm{e}, \mathrm{f}}$ \\
\hline & Middle & $3.87 \pm 0.09^{\mathrm{e}, \mathrm{f}}$ & $1.05 \pm 0.01^{\mathrm{c}, \mathrm{d}}$ & $2.81 \pm 0.07^{\mathrm{d}, \mathrm{e}}$ & $2.66 \pm 0.07^{\mathrm{d}, \mathrm{e}}$ \\
\hline & Head & $3.92 \pm 0.02^{\mathrm{e}, \mathrm{f}}$ & $0.95 \pm 0.00^{\mathrm{a}, \mathrm{b}}$ & $2.98 \pm 0.03^{\mathrm{f}, \mathrm{g}}$ & $2.82 \pm 0.02^{\mathrm{f,g}}$ \\
\hline \multirow{3}{*}{$\begin{array}{l}\text { D. dumetorum } \\
\text { (Yellow) }\end{array}$} & Tail & $3.80 \pm 0.01^{\mathrm{e}, \mathrm{f}}$ & $1.14 \pm 0.02^{\mathrm{e}, \mathrm{f}}$ & $2.67 \pm 0.03^{\mathrm{c}, \mathrm{d}}$ & $2.53 \pm 0.02^{\mathrm{c}, \mathrm{d}}$ \\
\hline & Middle & $3.49 \pm 0.08^{d}$ & $1.12 \pm 0.01^{\mathrm{e}, \mathrm{f}}$ & $2.37 \pm 0.09^{c}$ & $2.25 \pm 0.09^{c}$ \\
\hline & Head & $3.67 \pm 0.02^{\mathrm{d}, \mathrm{e}}$ & $1.14 \pm 0.01^{\mathrm{e}, \mathrm{f}}$ & $2.53 \pm 0.01^{\mathrm{c}, \mathrm{d}}$ & $2.40 \pm 0.01^{\mathrm{c}, \mathrm{d}}$ \\
\hline \multirow[t]{3}{*}{ D. esculenta (Large) } & Tail & $4.53 \pm 0.14^{\mathrm{i}, \mathrm{j}}$ & $0.95 \pm 0.01^{\mathrm{a}, \mathrm{b}}$ & $3.58 \pm 0.12^{\mathrm{i}, \mathrm{j}}$ & $3.40 \pm 0.11^{\mathrm{i}, \mathrm{j}}$ \\
\hline & Middle & $3.91 \pm 0.00^{\mathrm{e}, \mathrm{f}}$ & $0.92 \pm 0.00^{\mathrm{a}, \mathrm{b}}$ & $2.99 \pm 0.00^{\mathrm{f}, \mathrm{g}}$ & $2.85 \pm 0.00^{\mathrm{f}, \mathrm{g}}$ \\
\hline & Head & $4.31 \pm 0.12^{\mathrm{h}, \mathrm{i}}$ & $0.94 \pm 0.01^{\mathrm{a}, \mathrm{b}}$ & $3.37 \pm 0.11^{\mathrm{h}, \mathrm{i}}$ & $3.20 \pm 0.11^{\mathrm{h}, \mathrm{i}}$ \\
\hline
\end{tabular}

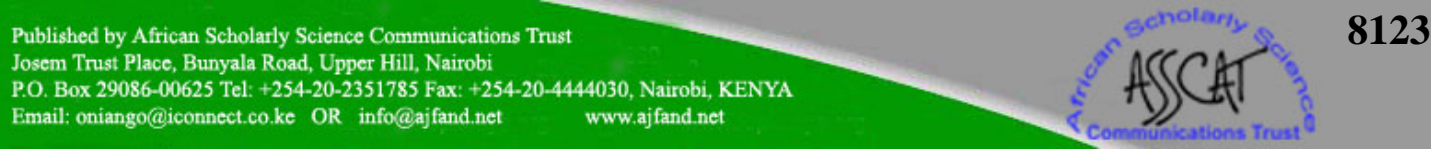




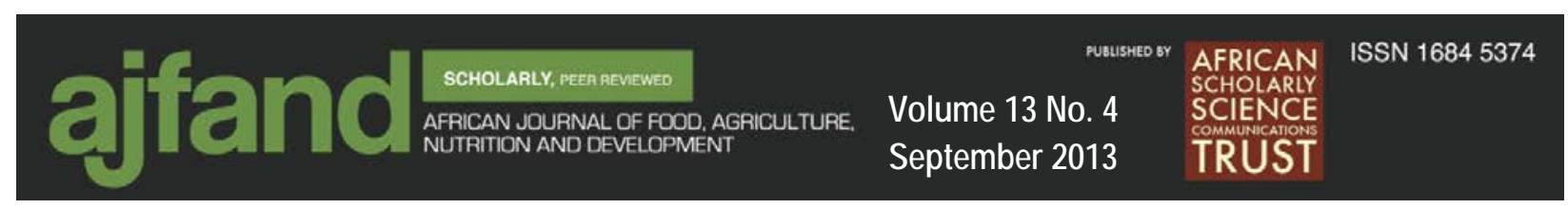

Table 2 continued: Free sugars in yam varieties

\begin{tabular}{llcccc}
\hline \multicolumn{1}{c}{ Yam variety } & Yam part & $\begin{array}{c}\text { Total Sugars } \\
\mathbf{( \% )}\end{array}$ & $\begin{array}{c}\text { Reducing Sugars } \\
\mathbf{( \% )}\end{array}$ & $\begin{array}{c}\text { Non-Reducing } \\
\text { Sugars (\%) }\end{array}$ & $\begin{array}{c}\text { Sucrose } \\
(\mathbf{\%})\end{array}$ \\
\hline D. cayenensis & Tail & $2.58 \pm 0.00^{\mathrm{b}}$ & $1.14 \pm 0.02^{\mathrm{e}, \mathrm{f}}$ & $1.43 \pm 0.02^{\mathrm{a}}$ & $1.36 \pm 0.01^{\mathrm{a}}$ \\
(Pure Yellow) & Middle & $2.16 \pm 0.04^{\mathrm{a}}$ & $0.99 \pm 0.02^{\mathrm{b}, \mathrm{c}}$ & $1.17 \pm 0.06^{\mathrm{a}}$ & $1.11 \pm 0.06^{\mathrm{a}}$ \\
& Head & $2.18 \pm 0.02^{\mathrm{a}}$ & $0.97 \pm 0.01^{\mathrm{a}, \mathrm{b}}$ & $1.22 \pm 0.00^{\mathrm{a}}$ & $1.15 \pm 0.00^{\mathrm{a}}$ \\
& & & & & $3.61 \pm 0.03^{\mathrm{j}}$ \\
D. bulbifera & Tail & $4.84 \pm 0.03^{\mathrm{k}}$ & $1.03 \pm 0.01^{\mathrm{b}, \mathrm{c}}$ & $3.81 \pm 0.04^{\mathrm{j}}$ & $3.64 \pm 0.17^{\mathrm{j}}$ \\
(Deep brown skin) & Middle & $4.74 \pm 0.14^{\mathrm{j}, \mathrm{k}}$ & $0.90 \pm 0.04^{\mathrm{a}, \mathrm{b}}$ & $3.83 \pm 0.18^{\mathrm{j}}$ & $3.58 \pm 0.07^{\mathrm{j}}$ \\
& Head & $4.82 \pm 0.03^{\mathrm{k}}$ & $1.05 \pm 0.04^{\mathrm{c}, \mathrm{d}}$ & $3.77 \pm 0.08^{\mathrm{j}}$ & \\
& & & & $1.76 \pm 0.03^{\mathrm{b}}$ & $1.67 \pm 0.03^{\mathrm{b}}$ \\
& Tail & $2.98 \pm 0.06^{\mathrm{c}}$ & $1.22 \pm 0.09^{\mathrm{f}}$ & $1.89 \pm 0.03^{\mathrm{b}}$ & $1.80 \pm 0.03^{\mathrm{b}}$
\end{tabular}

Values are Means \pm standard deviation from duplicate analyses. Those with the same superscripts in the same column are not significantly different $(\mathrm{P}<0.05)$

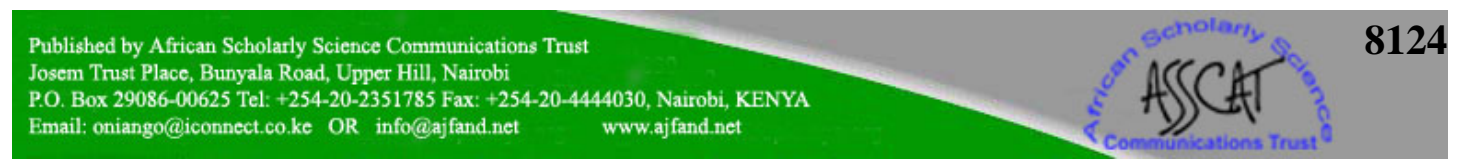




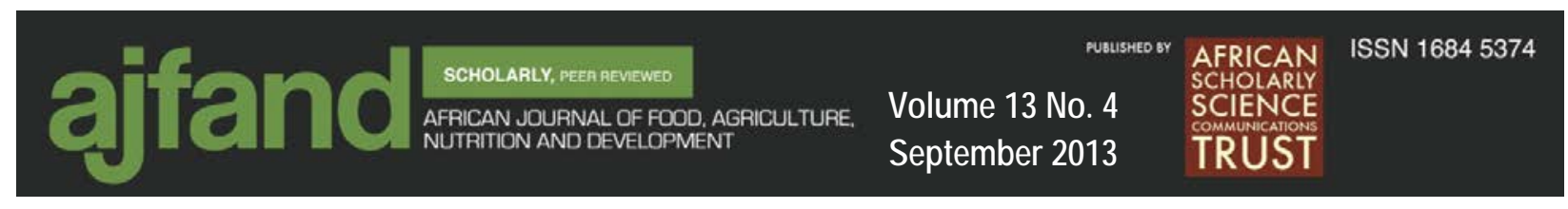

Table 3: Cell wall constituents in yam varieties (g/100g)

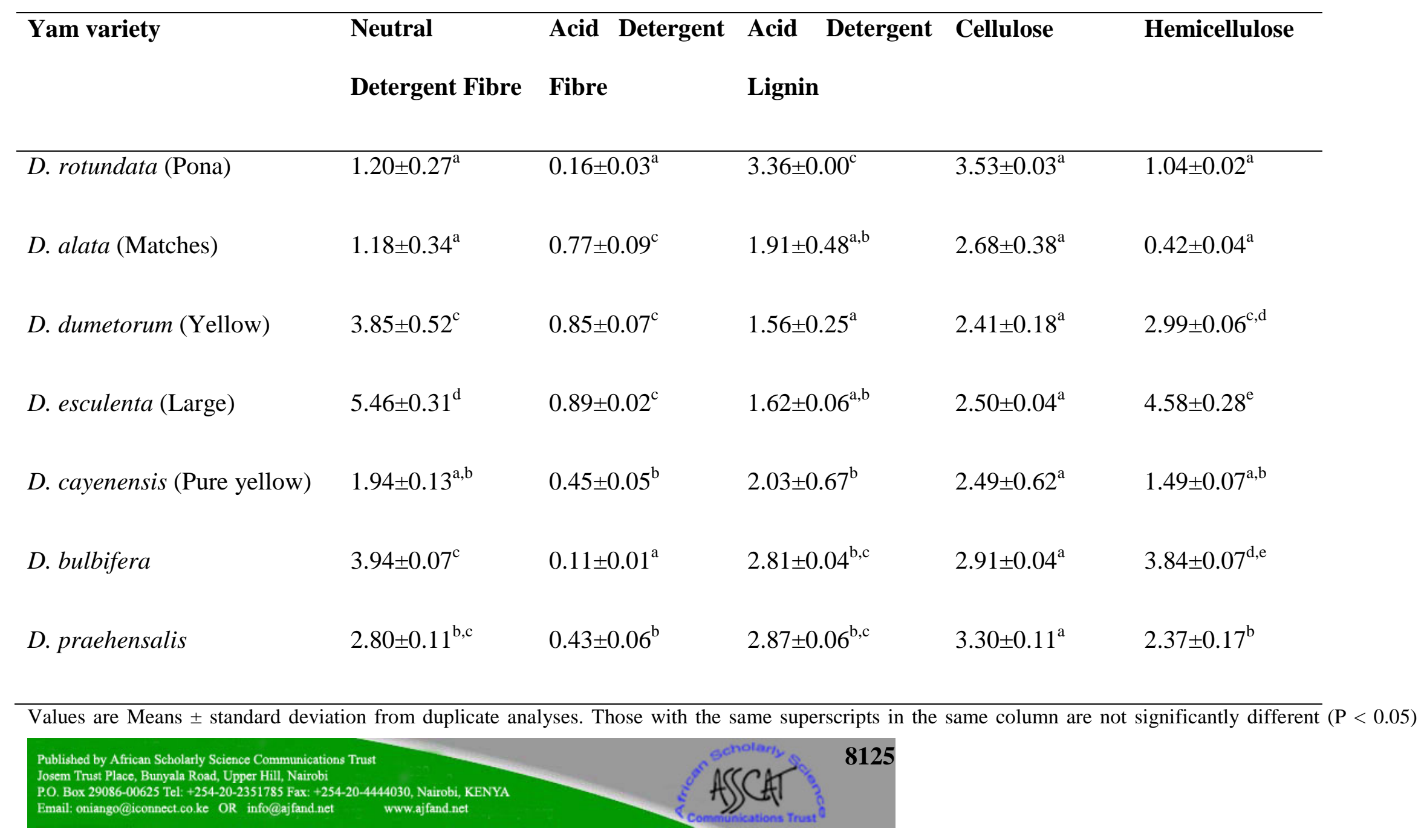




\section{REFERENCES}

1. Jayakody L, Hoover R, Liu Q and E Donner Studies on tuber starches. II. Molecular structure, composition and physicochemical properties of yam (Dioscorea sp.) starches grown in Sri Lanka. Carbohyd Polym 2007; 69: 148163.

2. FAO. Food and Agricultural Organisation of the United Nations. FAO Statistics 2009. FAO, Rome. 2008 http://faostat.fao.org/ Date retrieved: October 15, 2010.

3. Charles AL, Sriroth $\mathbf{K}$ and TC Huang Proximate composition, mineral contents, hydrogen cyanide and phytic acid of 5 cassava genotypes. Food Chem 2005; 92: 615-620.

4. Coursey DG Yam storage. 1: A review of yam storage practices and information on storage losses. J Stored Prod Res. 1967; 2: 229-244.

5. Amani NG, Kamenan A, Rolland-Sabaté A and P Colonna Stability of yam starch gels during processing. Afr J Biotechnol. 2005; 4 (1): 94-101.

6. Riley CK, Wheatley AO and HN Asemota Isolation and characterization of starches from eight Dioscorea alata cultivars grown in Jamaica. Afr J Biotechnol. 2006; 5 (17): 1528-1536.

7. DeCock P Functional properties of starch (Methods and applications). AgroFood-Industry Hi-Tech. 1996; 7(4): 18-22.

8. Alanazi FK, El-Bagory IM, Alsarra IA, Bayomi MA and MA Abdel-kawy Saudi-corn starch as a tablet excipient compared with imported starch. Saudi Pharm. J. 2008; 16(2): 112-121.

9. Osagie AU The yam in storage. Postharvest Research Unit, University of Benin, Nigeria, 1992.

10. Ketiku AO and VA Oyenuga Changes in the carbohydrate constituents of yam tuber (Dioscorea rotundata, Poir) during growth. J Sci Food Agric. 1973; 24: 367-373.

11. Treche $\mathbf{S}$ and $\mathbf{T}$ Agbor-Egbe Biochemical changes occurring during growth and storage of two yam species. Int J Food Sci Nutr. 47(2): 93-102.

12. Afoakwa EO and S Sefa-Dedeh Chemical composition and quality changes occurring in Dioscorea dumetorum pax tubers after harvest. Food Chem. 2001; 75: 85-91. 
13. Dje M, Dabonne S, Guehi ST and LP Kouame Monitoring of some biochemical parameters of two yam species (Dioscorea Spp.) tubers parts during post-harvest storage. Adv J. Food Sci Technol. 2010; 2 (3): 178-183.

14. Van Soest PJ Dietary fiber: Their definition and nutritional properties. Am. J. Clin. Nutr. 1978; 31: 12-20.

15. Abara AE, Tawo EN, Obi-Abang ME and GO Obochi Dietary fibre components of four common Nigerian Dioscorea species. Pak J Nutr. 2011; 10 (4): 383-387.

16. AOAC. Methods of the Association of Official Analysis Chemists. Official methods of analysis. 15th ed., Virginia Assoc. Off. Anal. Chem. USA, 1990: 1141.

17. Bainbridge $\mathbf{Z}$, Tomlins $\mathbf{K}$, Wellings $\mathbf{K}$ and $\mathbf{A}$ Westby Methods for Assessing Quality Characteristics of Non-Grain Starch Staples. Part 3. Laboratory Methods. Chatham, U.K.: Natural Resources Institute, 1996.

18. Sowbhagya CM and KR Bhattacharya A simplified colometric method for determination of amylase content in rice. Starch 1971; 23: 53-56.

19. Pearson D The chemical analysis of foods. Longman Group Limited, Seventh edition, UK, 1976: 126-129.

20. Van Soest PJ and RH Wine Use of detergents in the analysis of Dibrous Feeds. IV. Determination of plant cell-wall constituents. J. Assoc. Off. Anal. Chem. 1967; 50: 50-55.

21. Updegroff DM Semi-micro determination of cellulose in biological material. Anal Biochem 1969; 32: 420-424.

22. Agbor-Egbe $\mathbf{T}$ and $\mathbf{S}$ Treche Evaluation of the chemical composition of Cameroonian yam germplasm. J Food Compos Anal 1995; 8: 274-283.

23. Afoakwa EO and S Sefa-Dedeh Changes in cell wall constituents and mechanical properties during post-harvest hardening of trifoliate yam Dioscorea dumetorum (Kunth) pax tubers. Food Res Int 2002; 35: 429-434. 